\title{
Nutritional Status Evaluation of Grazed Yearling Kacang Bucks Estimated using Lignin Internal Indicator
}

\author{
Retno Adiwinarti ${ }^{1,2}$, I Gede Suparta Budisatria ${ }^{1}$, Kustantinah $^{1}$, Rusman ${ }^{1}$, Agung Purnomoadi ${ }^{2}$ \\ ${ }^{1}$ Faculty of Animal Science, University of Gadjah Mada, Jl. Fauna 3, Yogyakarta 55281, Indonesia \\ ${ }^{2}$ Faculty of Animal Agriculture, University of Diponegoro, Semarang 5027, Indonesia \\ Corresponding author email: retno_adi@yahoo.co.id; retno_adiwinarti@undip.ac.id
}

\begin{abstract}
In some areas in Indonesia, farmers usually graze their goats during the day and house them at night. The goats eat grass without additional concentrate. However, how much nutrient intakes of grazing goats in Indonesia are seldom calculated. Therefore, this research was set up to investigate the productivity and to estimate the dry matter, protein, and TDN intake of grazed Kacang buck using lignin internal indicator. About 12 heads of Kacang buck, aged 1-1.5 year (the incisors have erupted 1), having the initial body weight of $18.42 \pm 1.78 \mathrm{~kg}(\mathrm{CV}=9.67 \%)$ and reared by farmers in Grobogan, Central Java, Indonesia were used in this study. Intake and nutrient digestibility of the buck were calculated using lignin as internal marker. After being reared

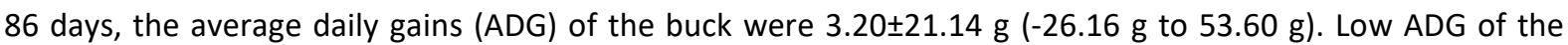
buck was caused by low DMI, protein and TDN intake. The Kacang bucks were usually grazed in the soccer fields, back yards, and roadsides, therefore their intake were lower than their maintenance needed. The averages of DMI, protein and TDN intake were about $1.17 \pm 0.17 \%$ their body weight, $30.16 \pm 4.18$ gand $91.45 \pm 11.64 \mathrm{~g}$, respectively.It can be concluded that the productivity of grazing Kacang bucks is relatively very low.
\end{abstract}

Key words: ADG, digestibility, grazing, intake, Kacang goat

Abstrak. Peternak di beberapa wilayah di Indonesia biasanya menggembalakan kambing di pagi hari kemudian dikandangkan saat malam. Kambing memakan rumput tanpa tambahan konsentrat. Namun berapa banyak asupan nutrisi kambing di Indonesia masih jarang dihitung. Dengan demikian, penelitian ini dilakukan untuk menilai produktivitas dan memperkirakan asupan bahan kering, protein dan TDN pada kambing Kacang yang digembalakan menggunakan indicator lignin internal. Duabelas kambing kacang jantan berusia $1-1,5$ tahun (incisors have erupted 1), dengan bobot awal $18,42 \pm 1,78 \mathrm{~kg}$ (CV=9,67\%) dan dipelihara oleh peternak di Grobogan, Jawa Tengah Indonesia digunakan untuk penelitian ini. Asupan dan kecernaan nutrisi kambing dihitung dengan lignin sebagai penanda internal. Setelah dipelihara selama 86 hari, rataan pertambahan bobot

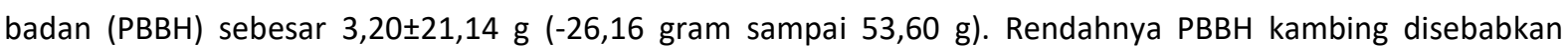
rendahnya asupan BK, protein dan TDN. Kambing Kacang biasanya digembalakan di lapangan sepak bola, pekarangan di belakang rumah, dan tepi jalan sehingga asupannya lebih rendah dari pemeliharaan yang dibutuhkan. Rataan asupan BK, protein dan TDN berturut-turut sebesar $1,17 \pm 0.17 \%$ bobot badan, $30,16 \pm 4,18 \mathrm{~g}$ dan $91,45 \pm 11,64 \mathrm{~g}$. disimpulkan bahwa produktivitas kambing Kacang yang digembalakan masih sangat rendah.

Kata kunci: PBBH, kecernaan, menggembalakan, asupan, kambing Kacang

\section{Introduction}

Goats have an important role in supporting economics of rural area people in Central Java, Indonesia. As reported in agricultural census data in 2013, the number of goats reared Central Java community was 3,461,409 heads, while sheep were only 533,616 heads (BPS, 2013). In addition, the number of goats 
slaughtered in 2013 were more than sheep, i.e. 764,645 compared to 333.318 heads, respectively (Central Java Statistics, 2013). It indicated that farmers preferred goats to sheep to rear and slaughter for meat.

Kacang goat is one of the local goats in Indonesia that farmers raise for saving because it can be sold at any time when they need cash and the price is relatively cheap so farmers can afford it. Elieser et al. (2012) stated that most farmers in rural area raise Kacang goats. Badan Litbang Pertanian (2013) reported that Kacang goat is one of the Animal Genetic Resources goats in Indonesia that is very adaptive to the limited environmental conditions (Elieser et al., 2012), especially well adapted to traditional management (Sianipar et al., 2005). This goat is relatively small (Supriadi, 2012), but has a good rate of reproduction (Panjono et al., 2012), therefore farmers get benefit from it. In addition, the percentage of Kacang goat carcass is relatively the same as Etawa crossbred goat and Kejobong goat with an average of $40.86 \%$ (Sumardianto et al., 2013), while Hutama (2014) reported about $46.67 \%$.

Kacang goats under intensive management showed increasing the body weight gain and feed efficiency linear to dietary crude protein and TDN content (Restitrisnani et al., 2013). In fact, most Kacang goats are traditionally (semi extensive) reared in smallholder farmers in rural area. In the lowlands of Central Java, Indonesia, $60 \%$ of goats were grazed in the fallow fields, roadsides, and soccer fields (Budisatria et al., 2010). The productivity of Kacang goats is low, because they eat grass without additional concentrates. However, research on the amount of feed consumption of graze Kacang goat is limited in Indonesia. The question is whether the graze goats got enough feed intake to meet nutrient needs.

Performance of goats reared traditionally by farmers (in situ) needs investigation because data of feed intake, nutritional status/nutrient adequacy, and body weight gain of graze goats are scarce. The problem is how to measure feed intake of grazing goat. Feed consumption and nutrient digestibility of graze goat were calculated using lignin as internal markers (Coleman, 2005). Dry matter digestibility and dry matter intake were calculated by the formula of Coleman (2005). These data serve as the basis for developing and evaluating the potential production of grazed Kacang goats. This study aims to investigate the performance and nutritional status of yearling grazed Kacang bucks, to determine the production (weight gain) and nutritional status (adequacy of dry matter intake, protein intake, and TDN intake).

\section{Materials and Method}

The research was carried out to farmers (in situ) who reared Kacang goats in Grobogan, Central Java, Indonesia. The materials used to evaluate the production of grazing goats were 12 male Kacang bucks approximately 1-1.5 years of age with initial body weight $18.42 \pm 1.78$ $\mathrm{kg}(\mathrm{CV}=9.67 \%)$ between 15 and $22 \mathrm{~kg}$. The goats were been chosen based on the characteristics of Kacang goat according to Supriadi (2012) and Kurnianto et al. (2013).

Goats generally graze in the yard around the house/football field/roadside, therefore feed consumption was calculated based on the digestibility of grass consumed using lignin as indicators (internal marker) and the weight of feces per day was measured to calculate the intake (Coleman, 2005).

Feces was collected using cloth feces bag. Adaptation of using feces bag was carried out for 2 weeks during which the feces was collected and measured. After the amount of feces was stable, the total fecal collection was continued everyday for two weeks. Body weight gain was observed before grazing (Ho Bunyeth and Preston, 2006) every other week for 8 weeks.

The parameters observed were nutrient intake and average daily gain (ADG). Feed 
consumption and nutrient digestibility were calculated using lignin as internal markers (Coleman, 2005). Dry matter digestibility and dry matter intake were calculated by the formula of Coleman (2005) as followed:

DM digestibility $(\%)=100-\left(100 \times \frac{\% \text { lignin in grass }}{\% \text { lignin in feces }}\right)$

DM intake $(\mathrm{g} /$ day $)=\frac{\text { daily fecal excertion }}{(1-\text { DM digestibility })}$

Nutrients digestibility (\%)

$=100-\left(100 \times \frac{\% \text { lignin in grass }}{\% \text { lignin in feces }} \times \frac{\% \text { nutrients in feces }}{\% \text { nutrients in grass }}\right)$

Average daily gain (g) was calculated as follows :

Final body weight (g) - initial body weight $(\mathrm{g})$ days of observation (days)

Data were analyzed descriptively to evaluate the productivity and nutritional status of grazing Kacang goat. The calculations of nutrients intake were then compared toprevious research to determine whether the feed intakes were sufficient for their production.

\section{Results and Discussion}

Nutrients content of field grass samples are presented in Table 1. The protein content of the grass in this study was lower than $22.60 \%$ in lowlands and $21.70 \%$ in highlands by $\mathrm{Ho}$ Bunyeth and Preston (2006), but higher than $7.8 \%$ by Osoro et al. (2007).

Initial body weight of Kacang goats was $18.42 \pm 1.78 \mathrm{~kg}$ ( $C V=9.67 \%)$ in $15-22 \mathrm{~kg}$ range, then increased after 86-day observation to $18.69 \pm 2.87 \mathrm{~kg}$ in 12.75 to $23.61 \mathrm{~kg}$ range. The goats had $3.20 \pm 21.14 \mathrm{~g}$ average daily weight gain. A total of 6 goats (50\%) showed $1.28 \mathrm{~g}$ increase in average body weight to $53.60 \mathrm{~g}$, while others decreased by $-0.81 \mathrm{~g}$ to $-26.16 \mathrm{~g}$.

Dry matter intake (DMI) can be estimated by calculating dry matter digestibility by the formula of Coleman (2005) using data of \% lignin in the grass and in the feces. The average lignin content in the grass was $16.52 \%$ (Table 1 ), while the lignin in the feces was about $25.10 \%$ $30.15 \%(27.31 \pm 1.76 \%)$.

The DMI was calculated using data of dry matter digestibility and the total dry matter feces excreted daily. Dry matter digestibility varied from $34.21 \%$ to $45.21 \%$ (39.29 $\pm 3.84 \%)$ (Figure 1), but still lower than $57.66 \%-68.36 \%$ of complete feed-fed Kacang goats raised intensively by Restitrisnani et al. (2013). It is because the crude fiber of natural grass $(34.87 \%)$ is higher than $26.23 \%-29.89 \%$ in the ration used in Restitrisnani et al. (2013).

Total dry matter of feces excreted daily was 103.43 to $172.79 \mathrm{~g}(131.56 \pm 23.90 \mathrm{~g})$. The estimated dry matter intake is presented in Table 2 and Figure 2.

The estimation intake of dry matter $(215.86 \pm 29.91 \mathrm{~g})$, protein $(30.16 \pm 4.18 \mathrm{~g})$, and TDN (91.45 $\pm 11.64 \mathrm{~g})$ of grazing Kacang goats were lower than that of Kacang goat fed with pellet complete feed containing $18.80 \%$ CP (Mukminah et al. 2015), scored 220-574 g DMI, 41-108 g CP, and 169-435 g TDN. It can be concluded that Kacang goat grazed in football grass areas, yards around the house and roadsides had not met their needs, both in terms of quantity and quality. These conditions worsened the growth of Kacang goat, even decreasing body weight in some goats. According to Sianipar et al. (2005), $12.80 \mathrm{~kg} \mathrm{DMI}$ of Kacangbucks was around $3.31 \%$ of their body weight. Hango et al. (2007) reported that African goat aged 10-16 months, $17.25 \pm 0.70$ $\mathrm{kg}$ can take 3.19\%-3.33\% DMI of their body weight. Dry matter intake of grazed Kacang goats in this study was $11.72 \pm 1.75 \mathrm{~g} / \mathrm{kg}$ $\mathrm{BW} /$ day. The DMI of grazed Kacang goat was lower than those reported by Aryanto et al. (2013) that voluntary feed intake of Kacang goats reached $29.42 \mathrm{~g} / \mathrm{kg} \mathrm{BW} /$ day.

The low feed digestibility (Figure 1) produced low amount of nutrients that can be utilized by goats for gaining weight. Average daily gain of grazed Kacang goat in this study $(3.20 \pm 21.14 \mathrm{~g} / \mathrm{head})$ was lower than $8 \mathrm{~g}$ in Small 
East African grazing goats (Mukandiwa et al., 2010), but higher than -25 gram in grazing Cashmere goats (Osoro et al. 2007) Schoenian
(2012) stated that grass-fed livestock usually gain lower than grain-fed livestock because of high moisture content in fresh forages.

Table 1. Nutrients content of field grass

\begin{tabular}{cccccccc}
\hline \multirow{2}{*}{ Samples } & DM & Ash & CP & EE & CF & NFE & Lignin \\
\cline { 2 - 8 } & $\%$ & & \multicolumn{2}{c}{$\%$ (in 100\% DM) } & \\
\hline 1 & 20.68 & 13.01 & 14.52 & 2.77 & 39.85 & 29.84 & 18.43 \\
2 & 26.42 & 11.29 & 12.98 & 3.48 & 32.71 & 39.54 & 14.30 \\
3 & 25.81 & 9.07 & 14.42 & 3.96 & 32.06 & 40.49 & 16.82 \\
\hline Averages & 24.30 & 11.12 & 13.97 & 3.40 & 34.87 & 36.62 & 16.52 \\
\hline
\end{tabular}

DM: dry matter; CP: crude protein; EE: ether extract; CF: crude fiber; NFE: nitrogen free extract

Table2. Nutrients Intakes (g/day) of Grazed Kacang Goats and the Average Daily Gain (g)

\begin{tabular}{ccccccc}
\hline No & ADG & DMI & EE intake & CP intake & CF intake & NFE intake \\
\hline 1 & 19.77 & 206.52 & 7.03 & 28.86 & 72.02 & 75.63 \\
2 & 53.60 & 198.26 & 6.75 & 27.71 & 69.14 & 72.61 \\
3 & -0.81 & 244.78 & 8.33 & 34.21 & 85.37 & 89.64 \\
4 & 20.35 & 183.71 & 6.25 & 25.67 & 64.07 & 67.28 \\
5 & -18.37 & 177.30 & 6.04 & 24.78 & 61.83 & 64.93 \\
6 & -5.93 & 224.79 & 7.65 & 31.41 & 78.39 & 82.32 \\
7 & -26.16 & 216.00 & 7.35 & 30.18 & 75.33 & 79.11 \\
8 & 10.93 & 238.09 & 8.10 & 33.27 & 83.03 & 87.19 \\
9 & 1.28 & 240.63 & 8.19 & 33.63 & 83.92 & 88.12 \\
10 & -12.33 & 166.86 & 5.68 & 23.32 & 58.19 & 61.11 \\
11 & 1.40 & 264.04 & 8.99 & 36.90 & 92.08 & 96.70 \\
12 & -5.35 & 229.31 & 7.81 & 32.04 & 79.97 & 83.98 \\
\hline Average & 3.20 & 215.86 & 7.35 & 30.16 & 75.28 & 79.05 \\
\hline Sd & 21.14 & 29.91 & 1.02 & 4.18 & 10.43 & 10.96
\end{tabular}

ADG: average daily gain; DMI: dry matter intake; EE: ether extract; CP: crude protein; CF: crude fibers; NFE: Nitrogen free extract

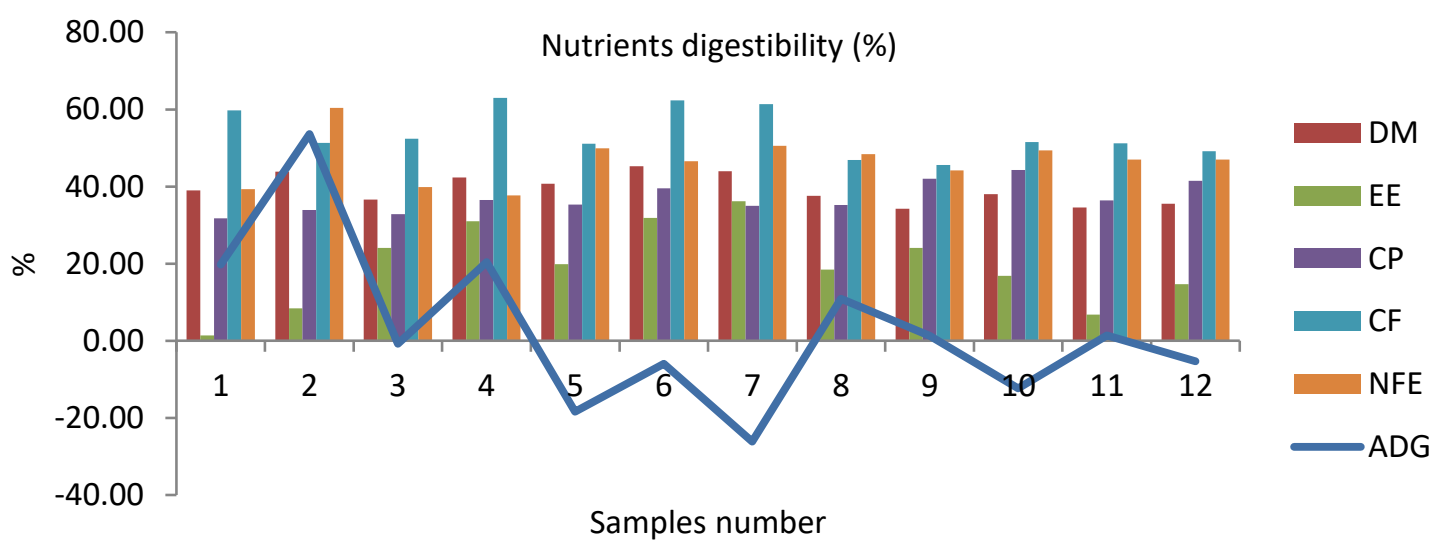

Figure 1. Nutrients digestibility (\%) of grazed Kacang Goats and the average daily gain (g) 


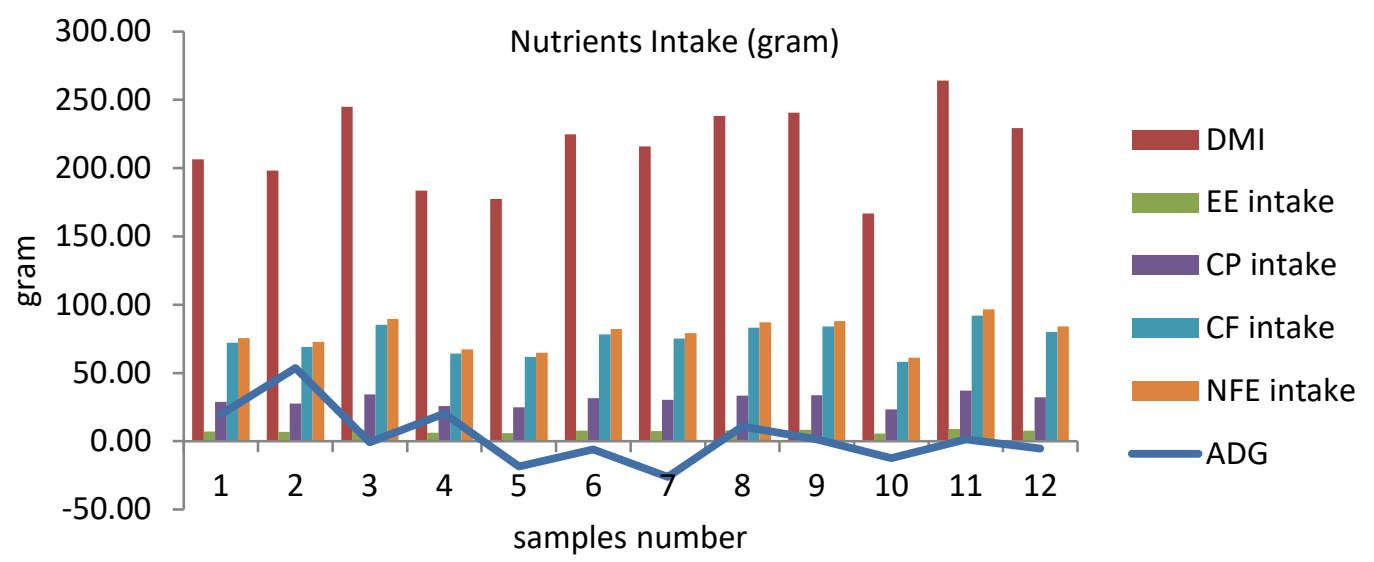

Figure 2. Nutrients intakes (g/day) of grazed Kacang Goats and the average daily gain (g)

The average feed efficiency of graze Kacang yearling was 8.89 (calculated from 6 heads of goats with body weight gain). The feed efficiency of Kacang goats in this study was higher than the ration-fed with $9.20 \%$ CP (4.24), but lower than that fed with $11.67 \%$ and $18.33 \%$ CP ration (10.63 and 11.73 ) as reported by Restitrisnani et al. (2013). Low feed efficiency of grazed Kacang goats might due to low feed digestibility of the grass and caused low ADG. Restitrisnani et al. (2013) stated that increasing CP and TDN content in the ration of Kacang goat have increased feed digestibility, feed utilization, and feed efficiency.

\section{Conclusions}

It can be concluded that nutrients intake, digestible nutrients, and nutrients digestibility of graze Kacang goat calculated using lignin internal indicator was very low. Therefore, it is needed to improve better management system (feeding and health) to increase the performance of graze Kacang goat.

\section{Acknowledgement}

The authors gratefully appreciate the Directorate General of Higher Education, Ministry of Education, Republic of Indonesia for Doctoral Program Scholarship (BPP-DN S3) and "Doctorate Dissertation Grant". Gratitude is also expressed to my family and my undergraduate students who have assisted for data collection.

\section{References}

Aryanto, B Suwignyo and Panjono. 2013. Effect of feed reduction and fulfillment on dry matter intake and digestibility of Kacang goat and Etawah crossbred goa. Buletin Peternakan. 37(1):12-18. DOI: http://dx.doi.org/10.21059/ buletinpeternak.v37i1.1954.

Badan Litbang Pertanian. 2013. Legality to protect the preservation of Kacang Goat. Retrieved Sept. 19, 2013, from http://www.litbang.deptan.go.id/ berita/one/1495/.

BPS (Badan Pusat Statistik). 2013. Population of Cattle Reared by Farmer Household based on The Types of Cattle According to Area and Types of Cattle. Retrieved Oct. 12, 2014 from http://st2013.bps.go.id/dev2/index.php/site/tab el tid=51\&wid=3300000000.

BPS Central Java (Badan Pusat Statistik, Provinsi Jawa Tengah). 2013. Cattle Slaughter According to Region/City in Central Java Year 2013.Retrieved Oct. 12, 2014 from http://jateng.bps.go.id/linkTabelStatis/view/id/1 007.

Budisatria IGS, HMJ Udo, CHAM Eilers, E Baliarti dan AJ van der Zijpp. 2010. Preferences for sheep or goats in Indonesia. Small Ruminant Research 88 (2010):16-22.

Coleman SW, 2005. Predicting forage intake by grazing ruminants. Florida Ruminant Nutrition Symposium. Brooksville, Florida. 72-90.

Elieser S, Sumadi, IGS Budisatria and Subandriyo. 2012. Productivity comparison between Boer and Kacang goat dam. J. Indonesian Trop. Anim. Agric. 37(1):15-21. 
Hango A, LA Mtenga, GC Kifaro, J Safari, DE Mushi and VRM Muhikambele. 2007. A study on growth performance and carcass characteristics of Small East African goats under different feeding regimes. Livestock Research for Rural Development. Vol. 19 No. 9, 2007. Retrieved May 8, 2014 from http://www.Irrd.org/Irrd19/9/ hang19130.htm.

Ho Bunyeth and TR Preston. 2006. Growth performance and parasite infestation of goats given cassava leaf silage, or sun-dried cassava leaves, as supplement to grazing in lowland and upland regions of Cambodia. Livestock Research for Rural Development. Vol. 18(2), Article \#28. Retrieved August 28, 2015, from http://www.Irrd.org/Irrd18/2/buny18028.htm.

Hutama YG. 2014. Percentage of Carcass and Non Carcass Component of Kacang Goat Due to Different Types of High Protein and Energy Feed. Skripsi Fakultas Peternakan dan Pertanian, Universitas Diponegoro. Retrieved Sept. 23, 2014 from http://eprints.undip.ac.id/42789/.

Kurnianto E, S Sutopo, E Purbowati, ET Setiatin, D Samsudewa and T Permatasari. 2013. Multivariate analysis of morphological traits of local goats in Central Java, Indonesia. Iranian J. Appl. Anim. Sci. 3(2): 361-367.

Mukandiwa L, PH Mugabe, TE Halimani and $\mathrm{H}$ Hamudikuwanda. 2010. A note on the effect of supplementing rangeland grazing with Acacia angustissima mixed with pearl millet on growth performance of goats in a smallholder farming area in Zimbabwe. Livestock Research for Rural Development. Vol. 22(1), Article \#9. Retrieved August 28, 2015 from http://www.Irrd.org/Irrd22/1/muka22009.htm.

Mukminah N, E Rianto and E Purbowati. 2015. Excretions of urinary creatinineon young and mature Kacang goat under different feeding levels. Animal Production 17(1):30-34.

Osoro K, A Mateos-Sanz, P Frutos, U Garcia, LM Ortega-Mora, LMM Ferreira, R Celaya and I Ferre. 2007. Anthelmintic and nutritional effects of heather supplementation on Cashmere goats grazing perennial rye grass-white clover pastures. J. Anim. Sci. 85(3):861-870.

Panjono, IGS Budisatria, G Murdjito, N Ngadiyono, and E Baliarti. 2012. Reproductive performance of Kacang, Kejobong and Ettawa grade goats does. Proceedings of the $15^{\text {th }}$ AAAP Animal Science Congress, Nov. 26-30, 2012. Thammasat University, Rangsit Campus, Thailand. 1274 1277.

Restitrisnani V, A Purnomoadi and E Rianto. 2013. The production and body composition of Kacang goat fed different quality of diets. J. Indonesian Trop. Anim. Agric. 38(3):163-170.

Schoenian S. 2012. Grass-fed lamb and goat. Small Ruminant Info Sheet. Retrieved Feb. 4, 2014 from http://www.sheepandgoat.com/articles/grassfed .html.

Sianipar J, A Batubara, S Karokaro and SP Ginting. 2005. Nutrient efficiency in Kosta, Gembrong and Kacang Goat. In: Proceeding of National Seminar Farming Technology and Veterinary. 2005. 630-636.

Sumardianto TAP, E Purbowati, and Masykuri. 2013. Carcass characteristics of one year old Kacang Goat, Ettawah crossbred, and male Kejobong goat. Anim. Agric. Journal. 2(1):175-182. Retrieved Sep. 19, 2013 fromhttp://ejournalS1.undip.ac.id/index.php/aaj.

Supriadi. 2012. Characteristics of Kacang Goat. Retrieved Sep. 19, 2013 from http://kembali alami.blogspot.com/2012/10/ciri-kambingkacang.html. 